\title{
Mahākhārata (Ādiparva, ch. 94).
}

There are references of the Kuru-Pānchāla war in the later Vedic and Sutra literature. But that the Pãndu story of the Mahābhärata Samhita, which gives the account of the two rival families of the Kauravas, could not in any way be called Kuru-Pānchāla story, is beyond all doubt.

As there is also mention in the later Vedic literature of the names of Dhritarāstra, Parikshit, and Janamejaya, it is still supposed by some that the Pāndu story, if not the same or a part of the Kuru-Pānchāla story, may be of equal antiquity. But $I$ think it can be with some certainty shown from the Mahābhārata itself that there was an old legend of a war between the Kurus and the Pānchālas which had no relation whatever with the Pāndu story.

I refer the readers to the 94 th chapter of the Ädiparva, giving the history of the Puruvamsa from the remotest antiquity. It has been distinctly stated (slokas 34 to 50) that Raja Sambarana (who was a Bhārata), being defeated by the Pānchālas, had to live with his whole family in the mountainous regions of the Panjab for a long time. This Sambarana is said to be the father of Raja Kuru. With the help of the Rishi Vasistha, the Raja got back the lost kingdom, and could make all other Rajas (Pānchālas not excepted) pay tribute to him. Kuru, son of Sambarana, founded Kurujāngala, famous since then as Kurukshetra.

We get also Janamejaya, Parikshit, and Dhritarāstra as some subsequent Rajas in the same family (slokas 51-56), who are far removed from the Rajas of the same name mentioned in the Pāndu story. Sāntanu himself is a successor of theirs; and this Sāntanu has been made in the Mahābhārata Samhita, the grandfather of the later Dhritarāstra and Pāndu. Thus we can easily explain how the names Janamejaya, Parikshit, and Dhritarāstra could be mentioned in very old literature, even though no Pāndu story existed.

I suspect that Dhritarāstra and Pāndu of the Mahābhārata were affiliated to the old renowned family for conferring dignity upon the heroes of the new story, and that the 
author of the Mahābhārata Samhita grafted his new story upon the Old Kuru Pānchāla or Bhāratī Kathā. There are passages in the Mahābhärata which show that facts which with propriety could only be mentioned in connection with the Kurus of old, have been with great inconsistency stated with reference to the modern Pāndavas. The Dhārtarāstras and Pāndavas were contending for supremacy over countries near about the Jamunā and the Gangā; and they had no manner of right over the portion of the Panjab which is watered by the Five Rivers, and had other kings for rulers. Yet, very curiously enough, it was agreed that the Dhārtarāstras would lose the kingdom of "Panchanadyah" if the Pandavas could not be traced by them during the stay of the Pandavas for twelve years in the forests (Vana Parva, 34th chapter, 11th sloka). The passage looks like a quotation in the mouth of Yudhisthira, and can be suspected to be the remnant of a portion of the old Kuru-Pānchāla story.

I need not multiply examples here, since I wanted in this paper merely to show that the legend about a war between the Kurus and Pānchālas existed in olden days, and that legend had nothing to do with the Pāndu story of the Mahābhārata.

B. C. Mazumdar. 